Check for updates

London

Cite this as: $B M J 2020 ; 371: \mathrm{m} 4848$ http://dx.doi.org/10.1136/bmj.m4848 Published: 15 December 2020

\section{Covid-19: Lateral flow tests miss over half of cases, Liverpool pilot data show}

\author{
Jacqui Wise
}

The rapid test kits most widely used in UK universities, schools, and care homes detect just $48.89 \%$ of covid-19 infections in asymptomatic people when compared with a polymerase chain reaction (PCR) test, real world data from the Liverpool pilot have shown.

The Innova Lateral Flow SARS-CoV-2 antigen test failed to detect three in 10 cases with the highest viral loads, in preliminary data released from the field evaluation of testing in asymptomatic people. ${ }^{1}$

The document was written by scientists at the University of Liverpool on 25 November but was released only 16 days later, by the Scientific Advisory Group for Emergencies (SAGE) on 11 December. It provides the details to a single line buried in a government paper from 30 November called Community Testing: A Guide for Local Delivery, which first reported the poor results of the test. ${ }^{23}$

The University of Liverpool document states that the Liverpool Health Protection Board decided as a result of the findings "to pause plans to use Innova Lateral Flow SARS-CoV-2 Antigen tests (LFT) in test-to-enable visitor access to care home settings due to the accuracy statistics”. Liverpool City Council resumed its pilot scheme in care homes on 3 December but only after requiring visitors to have two lateral flow tests and a confirmatory PCR test. The government put out new guidance for all care homes on 8 December stating that lateral flow tests should be used in addition to personal protective equipment and other infection control measures. ${ }^{4}$

\section{False reassurance}

Jon Deeks, professor of biostatistics at the University of Birmingham and leader of the Cochrane Collaboration's covid-19 test evaluation activities, told The BMJ, "These are the first results for this test in asymptomatic people. Normally, we would ascertain how well a test works before rolling it out in a nationwide programme. These findings raise concern that both the government's and individuals' expectations about how well this test works are not going to be met.

"Clearly, there is a risk of giving false reassurance to people who get a negative result. You also have to question whether mass screening using a test that performs so poorly is the best use of our limited resources."

The research compared the classifications of 3199 patients using military supervised self-administered lateral flow tests with those obtained when the same asymptomatic person used a second swab and a PCR test. A full dataset is expected to be released this Friday.
A false positive result occurred in two of 2981 PCR negative people-a specificity of $99.93 \%$ (99.76\% to 99.99\%). But lateral flow tests missed 23 of the 45 PCR positive participants, giving a sensitivity of $48.89 \%(33.70 \%$ to $64.23 \%)$.

The lateral flow tests missed a third of people with high viral load who had Ct scores (cycle threshold, a measure of virus) below 25-but seven of 15 cases with Ct scores of 20-25 were missed, giving a sensitivity of only $47 \%$ in this group ( $21 \%$ to $73 \%$ ). In people with Ct scores of 25-30, six of seven cases were missed-a sensitivity of $14 \%$ (o.4\% to $58 \%$ ). Deeks remarked, "We are seeing that it is really very poor at detecting covid in asymptomatic cases, even those with a higher viral load."

Richard Tedder, senior research investigator in medical virology at Imperial College London, commented, "This assay is simply not sensitive enough to use to test persons with a view to confirming an absence of infection and thereby an absence of infectivity. A negative result with this lateral flow test simply does not infer an absence of infection."

The findings contrast with an earlier assessment of the Innova test by Public Health England's Porton Down laboratory and the University of Oxford, which found an overall sensitivity of $76.8 \%$ but showed that sensitivity dropped to $58 \%$ when carried out by self-trained staff at a Boots track-and-trace centre. ${ }^{5}$

The government has spent more than $€_{700 m}\left(€_{767 \mathrm{~m}}\right.$; \$933m) buying the Innova kits, which are the lynchpin of its mass testing strategy. Over a million kits have been sent to care homes, and targeted testing is now being offered to secondary school children in parts of London, Kent, and Essex. Rapid lateral flow tests are also being used by most universities to test students before they return home to their families for Christmas, and only Cambridge offers PCR testing.

Scientific Advisory Group for Emergencies. Innova Lateral Flow SARS-CoV-2 Antigen test accuracy in Liverpool Pilot: preliminary data, 26 November 2020.11 Dec 2020. https://www.gov.uk/government/publications/innovalateral-flow-sars-cov-2-antigen-test-accuracy-in-liverpool-pilot-preliminarydata-26-november-2020.

2 Community testing: a guide for local delivery. 30 Nov 2020. www.gov.uk/government/publications/community-testing-explainer/community-testing-a-guide-for-local-delivery\#what-the-community-testingprogramme-is.

3 Wise J. Covid-19: Safety of lateral flow tests questioned after they are found to miss half of cases. BMJ 2020;371:m4744. doi: 10.1136/bmj.m4744 pmid: 33277265

4 Department of Health and Social Care. Care home LFD testing of visitors guidance. 8 Dec 2020. https://www.gov.uk/government/publications/coronavirus-covid-19-lateral-flow-testing-of-visitors-in-care-homes/care-homelfd-testing-of-visitors-guidance. 
5 Preliminary report from the Joint PHE Porton Down and University of Oxford SARS-CoV-2 test development and validation cell: rapid evaluation of lateral flow viral antigen detection devices (LFDs) for mass community testing. 8 Nov 2020. www.ox.ac.uk/sites/files/oxford/media_wysiwyg/UK\%20evaluation_PHE\%20Porton\%20Down\%20\%20University\%20of\%200xford_final.pdf.

This article is made freely available for use in accordance with BMJ's website terms and conditions for the duration of the covid-19 pandemic or until otherwise determined by BMJ. You may use, download and print the article for any lawful, non-commercial purpose (including text and data mining) provided that all copyright notices and trade marks are retained. 